\title{
Trade War between China and US
}

\author{
Zeyan Zhu' ${ }^{1, a}$, Yaotang Yang ${ }^{2, * b}$ and Shuqi Feng ${ }^{2, c}$ \\ ${ }^{1,2}$ School of Business Administration , Hohai University, Changzhou 213000, China \\ A15161167323@163.com,*Corresponding author Email: byangyaotang171@126.com, junjieopsz@163.com
}

Keywords: trade war,Sino-US trade , Section 301 investigation, “232 measure”.

\begin{abstract}
This paper introduces Sino-US trade war and trade situation between them,then research the influences of trade war to China and US,as well as global.We find that it will harm to both sides and other countries,including in economy, trade,diplomacy and many other fields. There will be more harm than benefit.Then we propose some suggestions, deepen the "Belt and Road" construction,improve the level of innovation,negotiation,and apply international regulations,for China to protect its interests and fight back trade war provoked by US.
\end{abstract}

\section{Introduction}

In the 1990s, the United States conducted "special 301 investigation" three times in China.As the largest source country of U.S. trade deficit, China has always been the focus of the U.S. trade war. U.S. President Trump officially signed Memorandum of Trade with China at the White House on March 23,which called "232 measure”.It refers to increasing tariffs on US\$60 billion of goods imported from China, and limiting Chinese companies' mergers and acquisitions in US.Sino-U.S. trade imbalance is the direct reason why Trump provoke the trade war.However,it is significant statistical differences between China and US which lead to U.S. trade deficit with China is overvalued by $20 \%$.

Once released,it has attracted worldwide attention,especially the leading role,China and U.S.. Additionally,it has a remarkable effect on Chinese,American,and European stock markets due to public concerns and pessimism.A shares in two markets suffered heavy losses on the same day. The three major stock indexes plummeted by more than 3\%, and over 3,000 stocks fell. In the afternoon, the valuation continued to decline.

Actually,the cloud of China-US trade war has not been dispersed,especially after Trump be in power, and this event marks the opening of a new round of Sino-US trade war.Therefore, What impacts will this trade war have on both sides, as well as global?Will it be beneficial to presenter-U.S. or lose?And what about China?

\section{Literature References}

U.S. and China are the top one and two countries in the world.Trade frictions between them has never disappeared,many scholars have researched the trade relationship between these two giants.After Trump took power,more and more people payed attention to Sino-US trade. Zhang Ming $^{[1]}$ and Wang Xuyang ${ }^{[2]}$ thought it was less possible for trade friction to upgrade to trade war.Li Xin used improved GTAP multi-countries and multi-sectors' computable general equilibrium model to simulate the different levels of Sino-US trade war and found that Sino-US trade war was ultimately more detrimental than beneficial to both countries ${ }^{[3]}$.KUANG Yan-xiang found that the probability of lower-level trade frictions would increase, but the probability of lower level trade frictions escalating to trade wars would decrease through constructing a multi-stage game model ${ }^{[4]}$.

Some other scholars explored the Sino-US trade connection and wanted to find countermeasures under trade friction or war.Ke Jianfei and YuLixin applied the operational loss theory of the Lanchester equation to simulate the impact of trade and showed that a trade war will have a huge impact on bilateral trade.Then they put forward some policy suggestions of countermeasures on 
expanding the market, enhancing own strength, perfecting the system and early warning system $^{[5]}$.Zhang Monan ${ }^{[6]}$ and Sun Jishan ${ }^{[7]}$ analyzed Sino-US trade problems and proposed corresponding strategies from a theoretical perspective.

\section{Sino-US Trade}

As the largest developing and developed country in the world,China and US possess the biggest market.Since they established diplomatic relations in 1979,Sino-US trade developed rapidly,especially after China joined the United Nations,their total trade increased from $\$ 5$ billion in 1980 to $\$ 583.7$ billion in 2017.China is the American biggest import market.In addition,since China exceeded Canada in 2015 for the first time,China has been the American largest cargo trading partner.On the other hand,US is the Chinese top one export market and one of the most important source of foreign investment.

According to the China customs data,in 2017, China's exports to the United States were US\$429.8 billion, an annual increase of $11.5 \%$, while imports from the United States were US\$153.9 billion, an increase of $14.5 \%$.The trade surplus between China and the US is as high as 275.8 billion U.S. dollars. Compared to 2016, the US $\$ 250.7$ billion increased by nearly $10 \%$, exceeding the historical record of 261 billion U.S. dollars in 2015, innovating an historical record .

Table 1 below shows the Sino-US trade condition in past ten years.And all data,except 2017(from China customs), is from the UN database.It demonstrates that there is always the trade surplus between China and the US.

Table 1 Trade Between China and US From 2008 To 2017(100 million U.S. dollars)

\begin{tabular}{ccccc}
\hline Years & Total Trade & China Export To US & China Import To US & Trade balance \\
\hline 2008 & 3344.3 & 2528.44 & 815.86 & 1712.58 \\
2009 & 2990.5 & 2212.95 & 777.55 & 1435.4 \\
2010 & 3865.14 & 2837.8 & 1027.34 & 1810.46 \\
2011 & 4481.35 & 3250.11 & 1231.24 & 2018.87 \\
2012 & 4872.04 & 3534.38 & 1337.66 & 2197.02 \\
2013 & 5224.59 & 3690.64 & 1533.95 & 2156.69 \\
2014 & 5571.64 & 3970.99 & 1600.65 & 2370.34 \\
2015 & 5586.72 & 4099.79 & 1486.93 & 2612.86 \\
2016 & 5207.98 & 3856.78 & 1351.20 & 2505.58 \\
2017 & 5837 & 4298 & 1539 & 2758 \\
\hline
\end{tabular}

\section{The Effect of Trade War}

\subsection{The Effect To US .}

Since China is the second largest country in the world and the American largest cargo trading partner,U.S. unilateral policy will lead to hurting the benefit of its residents and companies, who may have to sustain higher price goods or raw materials.It will increase residents' cost of living as well as companies' cost of production, which is harmful to US economic development in the end.

\subsection{The Effect To China .}

China is a big country in economy and trade.In 2017, China's exports to the United States were US $\$ 429.8$ billion,while imports from the United States were US\$153.9 billion. The trade surplus between China and the US is as high as 275.8 billion U.S. dollars.

Sino-US trade war will have a negative influence on Chinese economic development to some extend,as US is the Chinese biggest export market.But it will not change the trend of Chinese economic growth.First,the proportion of China's exports to the United States to China's GDP is not high,no more than 4\%.Second,with the implementation of "One Belt One Road", China has built up trade connection with many developing countries and exploited emerging markets, which replaces US market a lot.Third,China has put forward "Made in China" and advocated innovation in recent years.China's economic dependence on US has decreased.

\subsection{The Effect To Other Countries .}


There is no doubt that the trade war between the largest developing and developed country will harm to global economic and trade development and destruct trade relations.More seriously,it will impede globalization.Meanwhile,it is not conducive to the resolution of major hot spots in the world,such as rampant terrorism,seriously damaged ecological environment, and nuclear proliferation issues.Moreover, it will lead to the situation that all countries have to choose one of them to develop trade activities.

\section{Suggestions}

\subsection{Deepen the "Belt and Road" Construction .}

Through deepening the "Belt and Road" construction,the trade relations between China and countries along the route will be more valid.In the meaning time,China can open up new markets,including Africa,South Asia,West Asia,Central Asia,East Europe and so on,which will decrease trade dependence on US.

\subsection{Improve the level of China Innovation .}

Chinese companies should accelerate independent innovation and improve product technology content to improve international competitiveness and attract foreign investment.Government should improve intellectual property protection to encourage enterprise innovation.And for preventing industrial hollowing,we should focus on the development of the real economy and guide funds to flow to the manufacturing industry.

\subsection{Bilateral Negotiation .}

We should increase communication efforts between China and US not only at the government level,but also among the people and companies to promote invest by both parties.And both sides can consult about existential economic and trade issues.Meanwhile,we can utilize international publicity to promote free trade and contain unilateralism.

When negotiation,we should make flexible strategies and compromise appropriately.As for China,we can reduce restrictions of foreign investment and expand imports from US,like cars and agricultural products.And we also can prefect our legal system,especially intellectual property protection, which will beneficial to ourselves at the same time.We also should claim US to release or even cancel export restrictions to China, which will also decrease trade deficit for US.

\subsection{Apply International Regulations .}

WTO trade dispute resolution mechanism is effective weapon when faced with unfair treatment or trade friction.We should apply WTO trade dispute resolution mechanism to protect our rights and interests.And we also can take trade measurements to restrict Chinese companies importing from US or exporting to US.For example,increase import tariffs on products importing from US or export tariffs on rare earths which US imports from us.Coincidentally,we impose tariff reduction obligations on certain import commodities originating in the United States from April 2 to safeguard our interests and fight back “232 measure” put forward by US in March 23.

\section{Summary}

To sum up,both China and US should make efforts to maintain great trade relationship,rather than trade war.Otherwise,both side will suffer loss.Moreover,it will affect global trade order and lead to mass panic and social chaos.However,good trade links will beneficial to China,US,and other countries or organizations as well.

\section{References}

[1]. Zhang Ming,Zheng Liansheng,Wang Yuzhe,Yang Xiaochen,Zhou Ji.Unlikely full trade war between China and U.S. [J].China Forex,2017(06):26-29.

[2]. Wang Xuyang.When both are combined,the bucket will hurt - Sino-U.S. Economic and Trade Relations Move Forward in Friction[J].Modern Management Science,2018(02):54-56+93. 
[3]. Li Xin.The Scenarios of Sino-US Trade War: Based on the GTAP CGE Mode[J].Journal of International Trade,2012(11):50-65.

[4]. KUANG Yan-xiang.Economic Interdependence and Sino-US Trade Frictions: a Research Based on Multi-stage Game Model [J].Journal of International Trade,2010(11):36-43.

[5]. Ke Jianfei,Yu Lixin.Trade war under the background of economic globalization:theoretical analysis and China’s countermeasures[J].Globalization,2017(06):71-84+135-136.

[6]. Zhang Monan.Research on Launching a new model of China-Us Eeonomic Cooperation and Reduce Trade Fictions[J].Regional Economic Review,2017(06):99-104.

[7]. Sun Jishan.Where does Sino-US economic and trade go?-- Analysis of trade imbalance between China and the United States and the options for dealing with trade wars[J].Intertrade,2017(11):31-33+40.

[8]. Information on: https://comtrade.un.org 